\title{
Analisa Perubahan Gaya Angkat dan Hambatan Total Terhadap Variasi Aspect Ratio dan Winglet pada Sayap Kapal Wing in Surface Effect Menggunakan Aplikasi CFD
}

\author{
Rahmat Diko Edfi dan I.K.A.P. Utama \\ Departmen Teknik Perkapalan, Fakultas Teknologi Kelautan, Institut Teknologi Sepuluh Nopember (ITS) \\ e-mail: kutama@na.its.ac.id
}

\begin{abstract}
Abstrak---Pada proses desain kapal Wing In Surface Effect (WISE) sangat diperhatikan masalah gaya hambat serta gaya angkat yang terjadi saat kapal melaju dalam mode ground effect. Salah satu cara untuk mengurangi gaya hambat kapal WISE adalah dengan meningkatkan nilai aspek rasio sayap dan memodifikasi winglet. Untuk membuktikan hal tersebut, dalam penelitian ini dilakukan simulasi Computational Fluid Dynamics (CFD) dengan cara membandingkan sayap dengan aspek rasio rendah (AR=1) dengan aspek rasio sedang $A R=3$ serta memvariasikan sudut cant pada winglet. Hasil dari simulasi aspek rasio yang dilakukan menunjukkan nilai gaya hambat dan gaya angkat yang berbeda di setiap variasi kecepatan. Kapal WISE dengan aspek rasio sedang $\mathrm{AR}=3$ memiliki nilai gaya hambat yang lebih kecil dibandingkan dengan kapal WISE dengan aspek rasio rendah $(A R=1)$. Kapal WISE dengan aspek rasio sedang $A R=3$ memiliki nilai gaya angkat yang lebih besar dibandingkan dengan kapal WISE dengan aspek rasio rendah $(A R=1)$. Hal ini dikarenakan induced drag yang dihasilkan model $A(A R=1)$ lebih besar dari model $B(A R=3)$. Jadi konfigurasi aspek rasio terbaik yang didapatkan dari penelitian ini adalah aspek rasio sedang (AR=3). (Hasil simulasi yang dilakukan pada variasi sudut cant winglet kapal WISE menunjukan nilai gaya hambat dan gaya angkat yang berbeda di setiap variasi sudut). Kapal WISE dengan sudut cant winglet $\alpha=45^{\circ}$ mempunyai gaya hambat yang lebih kecil dibandingkan dengan sudut cant winglet $\alpha=30^{\circ}$ dan $\alpha=60^{\circ}$ sehingga konfigurasi aspek rasio terbaik yang didapatkan dari penelitian ini adalah aspek rasio sedang $(\mathrm{AR}=3)$. Kapal WISE dengan sudut cant winglet $\alpha=30^{\circ}$ mempunyai gaya angkat yang lebih besar dibandingkan dengan sudut cant winglet $\alpha=45^{\circ}$ dan $\alpha=60^{\circ}$. Sehingga semakin besar sudut cant maka nilai gaya angkat yang dihasilkan semakin kecil dan konfigurasi sudut cant terbaik terhadap nilai gaya hambat adalah pada sudut $\alpha=45^{\circ}$.
\end{abstract}

Kata Kunci-WISE, Ground Effect, CFD, Aspek Rasio, Sudut cant dan Winglet.

\section{PENDAHULUAN}

$\mathrm{T}$ ERWUJUDNYA cita cita Indonesia sebagai poros maritim dunia harus diawali dengan didukungnya teknologi yang memadai di dalam mengelola dan menjaga di setiap sektor laut yang ada. Hal ini menjadi tanggung jawab baru untuk terus meneliti dan mengembangkan teknologi di bidang transportasi laut, untuk menunjang cita-cita Indonesia sebagai poros maritim dunia. Transportasi laut merupakan ujung tombak di dalam membangun sumber daya maritim dimana transportasi laut terkhususnya kapal harus bisa mengakomodasi segala aktifitas yang berhubungan dengan laut. Oleh sebab itu dibutuhkan segala upaya untuk meningkatkan performa dari setiap jenis transportasi laut yang ada seperti kecepatan, kekuatan, efisiensi bahan bakar dan lain lain [1].

Salah satu aktifitas laut Indonesia yang saat ini masih tertinggal jauh dari negara lain adalah pertahanan nasional. Dimana pada sektor pertahanan Indonesia yang memiliki wilayah laut yang sangat luas ini dibutuhkan teknologi transportasi yang mampu bergerak cepat dan mampu menjangkau setiap area laut yang ada. Pada kondisi saat ini Indonesia sudah memiliki beberapa kapal patrol cepat guna menjaga wilayah perairan yang ada namun masih memiliki kekurangan seperti pemakain bahan bakar yang masih kurang efisien serta dinilai masih kurang cepat untuk mengejar kapal kapal asing yang berteknologi tinggi [2].

Melihat kondisi tersebut, perlunya adanya kapal WISE sebagai kapal patroli untuk meningkatkan kualitas pertahanan nasional Indonesia di wilayah laut. Dibandingkan pesawat, WISE lebih ekonomis karena tenaga yang digunakan untuk kapal ini dapat terbang rendah hanya separuh dari tenaga pesawat saat terbang tinggi . Hal ini disebabkan karena ketika terbang rendah dekat dengan permukaan laut, sayap WISE mendapat efek tekanan udara yang besar dari bawah sayap. Pada prinsipnya, WISE memanfaatkan efek pemampatan udara permukaan yang terjadi pada saat kapal terbang rendah. Efek ini dipertahankan dengan menjaga kecepatan yang disesuaikan dengan bobot dan rancangan kapal [3].

Penelitian dan pengembangan dapat dilakukan dengan menganalisa aspek rasio dari sayap utama kapal serta analisa sudut cant pada winglet, dimana dari hasil analisa didapatkan rancangan yang memiliki gaya angkat yang besar namun tetap memiliki tahanan yang kecil.

\section{TINJAUN PUSTAKA}

\section{A. Fenomena Ground Effect / Wing in Surface Effect}

Pada prinsipnya WISE memanfaatkan efek pemampatan udara permukaan yang terjadi pada objek benda yang terbang rendah. Efek ini dipertahankan dengan memilih kecepatan yang tepat dan rekayasa bentuk benda yang sedemikian aerodinamis sehingga benda tersebut dapat tetap melayang di atas permukaan air karena pengaruh gaya efek permukaan air. Gaya angkat pada sayap terjadi akibat adanya perbedaan tekanan dipermukaan atas dan permukaan bawah sayap akibat gerak relatif udara terhadap sayap [4].

Pada fenomena ground effect, bantalan udara dinamik yang timbul ketika kapal terbang sangat rendah di atas permukaan 
dapat meningkatkan rasio gaya angkat dan gaya hambat (lift to drag ratio). Hal ini mengakibatkan terjadinya efisiensi bahan bakar yang lebih baik daripada pesawat konvensional. Keseluruhan efek yang terjadi, dapat menaikkan rasio gaya angkat / gaya hambat (L/D), sehingga ketika WiSE terbang lebih dekat dengan permukaan, maka gaya angkat yang dihasilkan oleh sayap akan bertambah dengan gaya hambat yang berkurang. Oleh karena itu, terbang dalam ground effect, menghasilkan sebuah gaya angkat besar yang menimbulkan penurunan hambatan dengan efisiensi laju yang tinggi [3].

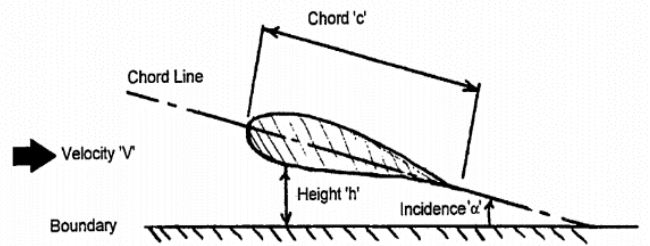

Gambar 1. Wing in Ground Effect [3].

\section{B. Teori Aerodinamika}

Karakteristik aerodinamika sebuah pesawat terbang dapat diukur performanya berdasarkan nilai lift dan drag yang dihasilkan. Lift dan drag yang dihasilkan oleh sebuah pesawat terbang tergantung pada performa sayap dan atribut pendukungnya. Saat pesawat terbang bergerak maka menghasiltan resultan gaya yang saling berlawanan arah yaitu nilai lift yang berlawanan dengan gaya berat dan nilai drag yang berlawanan dengan thrust [5].

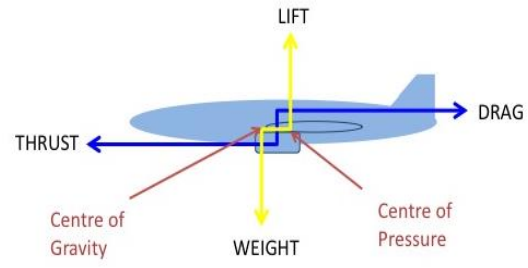

Gambar 2. Resultan Gaya Yang Bekerja Pada Pesawat terbang [6].

Drag merupakan gaya yang berlawanan dengan arah gerak benda. Besar gaya ini berbanding lurus dengan nilai kecepatan benda. Drag pada pesawat terbang terbagi menjadi dua kategoti yaitu friction drag dan induction drag. Friction drag merupakan gaya yang ditimbulkan akibat gesekan udara terhadap permukaan pesawat terbang. Induction drag akibat dari konsekuensi gaya angkat yang dihasilkan oleh aerofoil (misalnya sayap atau tailplane) melalui aliran udara. Udara yang mengalir di atas sayap cenderung mengalir ke dalam karena penurunan tekanan di atas permukaan atas kurang dari tekanan di luar ujung sayap. Di bawah sayap, udara mengalir keluar karena tekanan di bawah sayap lebih besar daripada di luar ujung sayap. Hal ini mengakibatkan terjadinya aliran udara yang terus-menerus ke atas di sekitar ujung sayap, fenomena tersebut dikenal dengan istilah tip effect atau end effect [7].

\section{Savitsky Planing Method}

Savitsky method merupakan metode untuk menghitung kapal cepat yang termasuk di dalam kategori planing hull. Kapal planing hull merupakan salah satu jenis kapal yang mempunyai tingkat efisiensi yang baik sebagai kapal cepat. Kapal ini bergantung pada kecepatan yang mengangkat sebagian lambungnya keluar dari air (hydrodynamic support). Dengan kecilnya badan kapal yang bersentuhan dengan air maka kecil juga jumlah tahanan air yang ditanggung. Bentuk badan kapal dirancang mengikuti hukum hidrodinamika ,setiap benda yang bergerak yang dapat menciptakan aliran non-simetris menimbulkan gaya angkat yang tegak lurus dengan arah gerak [8].

Seperti sayap pesawat terbang yang bergerak di udara akan memberi gaya angkat

- $\quad$ koefisien lift dengan sudut deadrise $0^{\circ}$,

$$
\begin{aligned}
& C_{L 0}=\tau^{1.1}\left[0.0120 \lambda^{1 / 2}+0.0055 \frac{\lambda^{2.5}}{C_{V}{ }^{2}}\right] \\
& \text { - } \quad \text { koefisien lift dengan sudut deadrise, } \\
& C_{L \beta}=C_{L 0}-0.0065 \beta C_{L 0}{ }^{0.6} \\
& \text { dimana } \\
& \lambda=\text { Mean Wetted Length-Beam Ratio } \\
& \tau \quad=\text { Sudut Trim } \\
& \text { CL } \beta=\text { koefisien gaya angkat pada kapal dengan } \\
& \text { sudut deadrise } \\
& \beta \quad=\text { sudut deadrise } \\
& \text { CL0 = koefisien gaya angkat pada kapal dengan } \\
& \text { sudut deadrise } 0^{\circ}
\end{aligned}
$$

Lalu untuk menentukan titik pusat gaya angkat atau center of pressure yang diterima kapal saat dalam fase planing maka dapat dihitung dengan menggunakan persamaan berikut

$$
C_{P}=0.75-\frac{1}{5.21\left(\frac{C_{V}}{\lambda}\right)^{2}+2.39}=\frac{l_{p}}{\lambda b}
$$

\section{NACA Series}

Geometri airfoil memiliki pengaruh besar terhadap karakteristik aerodinamika dengan parameter penting berupa $\mathrm{CL}$, dan kemudian akan terkait dengan lift (gaya angkat yang dihasilkan. NACA (National Advisory Committe for

\begin{tabular}{|c|c|}
\hline & Units \\
\hline \multirow{2}{*}{$\begin{array}{l}\text { MTOW } \\
\text { Payload [Including F.O] }\end{array}$} & $3.350 \mathrm{Kg}$ \\
\hline & $1.450 \mathrm{Kg}$ \\
\hline Empty Weight & $1.900 \mathrm{Kg}$ \\
\hline Pilot \& Copliot & 2 Person \\
\hline Crew & 8 Person \\
\hline Engine & $\begin{array}{r}\text { PWC PT6A-34 Turboprop } \\
\text { (750) }\end{array}$ \\
\hline Flight Distance & $800 \mathrm{Km}$ (WIG Effect Mode) \\
\hline \multirow{2}{*}{ Flight Speed } & $220 \mathrm{~km} / \mathrm{h}$ \\
\hline & $200 \mathrm{~km} / \mathrm{h}$ \\
\hline Ship Mode Speed & $1-54 \operatorname{Knots}(100 \mathrm{~km} / \mathrm{h})$ \\
\hline Flight Altitude & $150 \mathrm{~m}$ \\
\hline $\begin{array}{l}\text { Significant Wave Height (Take- } \\
\text { off/Landing) }\end{array}$ & $1.8 \mathrm{~m}$ \\
\hline
\end{tabular}
Aeronautics) merupakan standar dalam perancangan suatu airfoil. Perancangan airfoil pada dasarnya bersifat khusus dan dibuat menurut selera serta sesuai dengan kebutuhan dari pesawat yang akan dibuat. Akan tetapi NACA menggunakan bentuk airfoil yang disusun secara sistematis dan rasional. NACA mengidentifikasi bentuk airfoil dengan menggunakan sistem angka kunci seperti seri " satu ", seri “ enam ”, seri “ empat angka ", dan seri " lima angka " [6].

\section{E. Data kapal Aron M80}

Tabel 1.

Data kapal Aron M80 


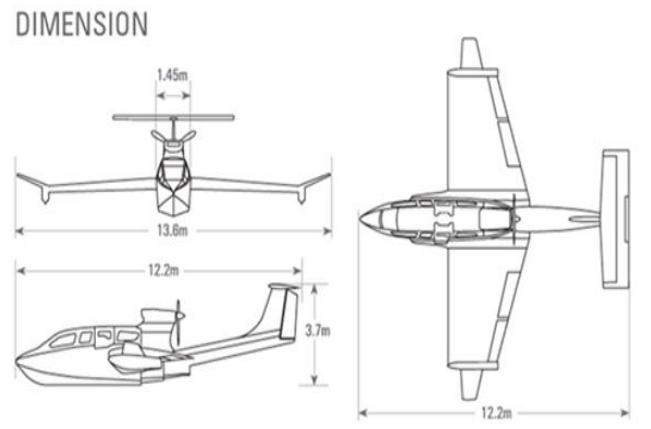

Gambar 3. Dimensi Kapal WISE Aron M80 [9].

Aron M80 merupakan desain kapal WiSE buatan korea. Data kapal ini akan digunakan sebagai acuan atau data kapal pembanding untuk pembuatan model yang akan dianalisa terkait konfigurasi aspect ratio dan variasi sudut cant winglet menggunakan software CFD . Data kapal Aron M80 dapat dilihat pada Tabel 1:

\section{F. Desain WIG Craft Alexander Lippichs}

Alexander Lippichs mengembangkan salah satu dari Wing in Ground Craft dengan nama prototipe X-112 pada tahun 1963. Bentuk planform sayap dari kapal WIG yang dikembangkan menggunakan tipe reverse delta wing aspek ratio rendah. Konfirgurasi tipe ini dipatenkan dengan nama Lippichs planform. Desain reversed delta wing Lippich planform dilaporkan pada pergerakan rendah dekat permukaan mampunyai nilai lift to drag ratio yang tinggi [3].

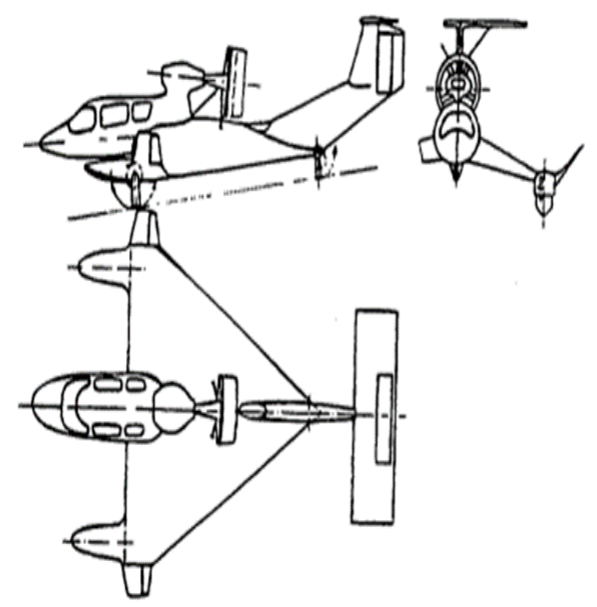

Gambar 4. Desain WIG Alexander Lippichs [3].

Desain paten planform Alexander Lippich telah dibeli oleh perusahaan german RFB company yang telah mendesain beberapa WIG yang mengacu pada planfrom Alexander Lippichs. WIG craft yang telah teruji digunakan untuk keperluan militer dan akan dikembangkan untuk kepentingan parawisata. Desain planfrom Alexander Lippichs tidak dirancang untuk kapal berdisplacement besar seperti Russian Ekranoplans [3].

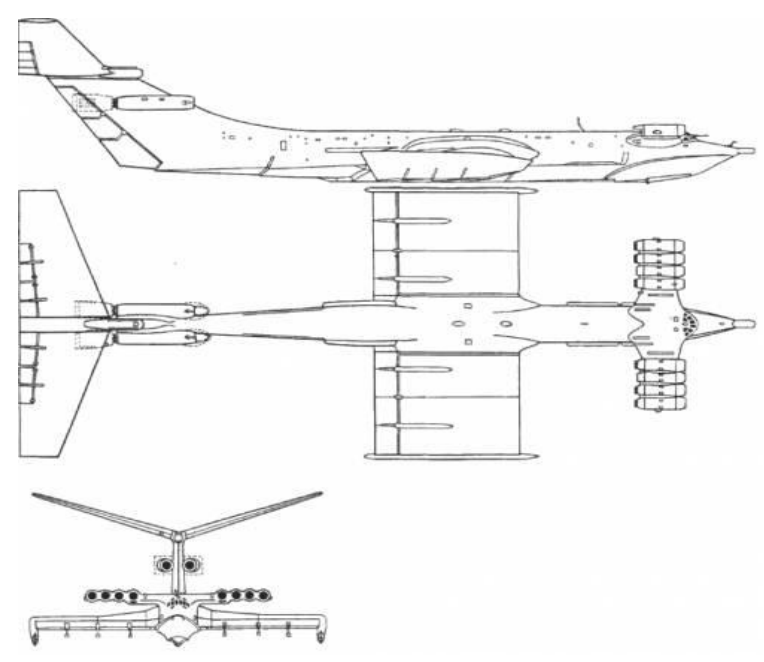

Gambar 5. Desain Russian Ekranoplane [10].

Ecranoplane merupakan WIG terbesar yang akan dibangun adalah oleh Russia. WIG ini dikenal dengan sebutan "Monster Laut Kaspia" dengan displacement sebesar 500 ton. WIG ini dibangun pada 1963 sebagai prototipe dan digunakan untuk menguji berbagai aspek desain WIG [3].

Ecranoplane yang dirancang oleh CDBHC di tahun 1960-an hingga 1980-an merupakan WIG generasi pertama. Rancangan WIG ini telah diakui tidak effisien pada sejumlah level. 1. WIG ini secara struktural tidak efisien dengan bobot structural yang tinggi dibandingkan dengan berat payload. Hal ini terutama berasal dari penguatan lambung kapal yang lebih buruk dari yang diharapkan.

2. Performa saat pendaratan dan take off tidak lebih baik dari pesawat amfibi, hal ini dikarenakan ecranoplane membutuhkan daya dorong yang tinggi untuk lepas landas.

3. WIG ini mengalami masalah terhadap korosi karena lingkungan operasi. Terkhususnya, ada kesulitan dengan mesin mudah korosi akibat faktor lingkungan. Keandalan struktural juga menjadi masalah dalam lingkungan korosif seperti itu.

4. Performa aerodinamis WIG ini paling baik dan setara dengan pesawat. Hal ini dikarenakan bentuk dan konfigurasi yang mirip dengan pesawat [3].

\section{G. Aspect Ratio}

Penelitian terkait aspek ratio pada pesawat pertama kali dilakukan oleh wright bersaudara dengan wind tunnel. Wright bersaudara menemukan bahwa drag yang dihasilkan oleh sayap yang memiliki span yang panjang (high aspect ratio) lebih kecil dibandingkan dengan sayap yang memiliki span yang pendek (low aspect ratio). Di area planform bentuk sayap persegi yang paling sederhana, aspek rasio didefinisikan sebagai span kuadrat dibagi luasan planform sayap pesawat [6].

\section{H. Winglet}

Richard T. dari NASA menemukan ekstensi wingtip vertikal pada awal tahun 1970-an sebagai sarana yang memungkinkan peningkatan nilai lift to drag pesawat. Pada tahun 1976 , penelitian [9]. menunjukkan bahwa winglet mengurangi induced drag hingga $20 \%$, menghasilkan sekitar 9\% lift to drag yang lebih baik di 0,78 mach untuk konfigurasi sayap tertentu. 
Kesimpulan dari penelitian tersebut adalah winglet menghasilkan dua kali manfaat dari ekstensi wingtip dengan luas area yang setara [11].

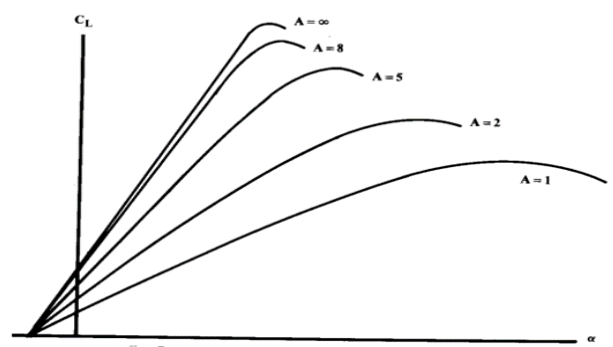

Gambar 6. Kurva Aspek Rasio Terhadap Koefisien Lift [6].

\section{Simulasi Full Viscous}

Simulasi CFD full viscous yang dilakukan pada model kapal WISE menggunakan pendekatan simulasi wind tunnel. Model uji dikondisikan berada pada posisi aktual benda pada kondisi sebenarnya terhadap permukaan air, dalam pengujian ini permukaan air disebut dengan ground.

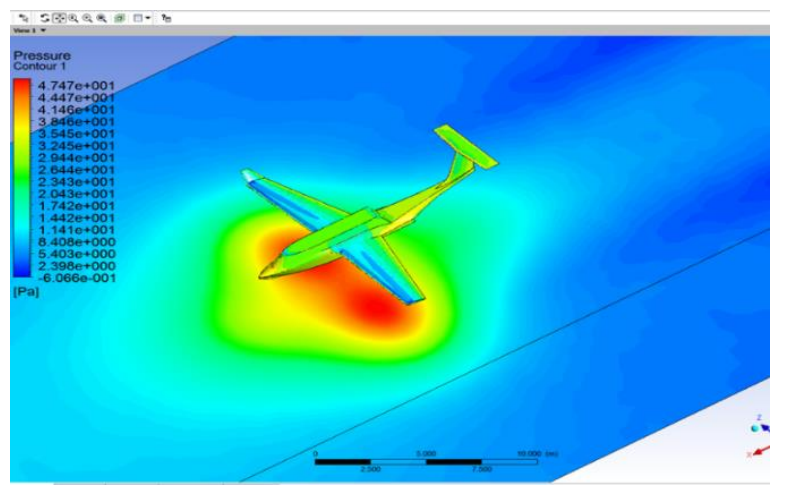

Gambar 7. Hasil Simulasi Full Viscous.

\section{J. Simulasi Free Surface}

Simulasi CFD free surface memiliki tingkat sensitifitas yang tinggi terhadap pengaturan boundary condition jika dibandingkan dengan mode simulasi dasar lainya. Diperlukan ketelitian yang tinggi dalam proses pengaturan simulasi ini. Simulasi free surface dilakukan menggunakan pendekatan simulasi towing test dimana fluida yang mengaliri kapal terdiri dari air dan udara.

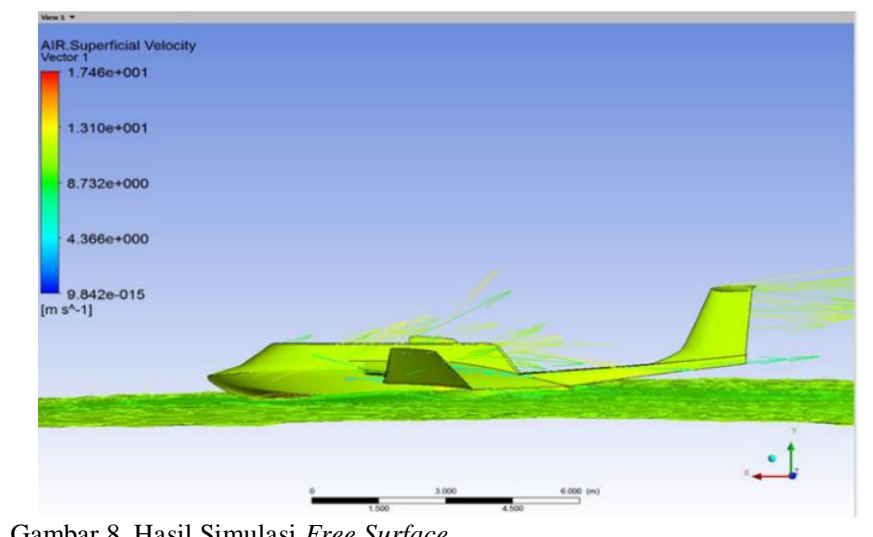

Gambar 8. Hasil Simulasi Free Surface.

\section{METODOLOGI}

Seperti yang disinggung sebelumnya, tahap pertama dari pengerjaan penelitian ini adalah studi literatur yang bertujuan untuk mengumpulkan dasar dasar teori yang diperlukan sebagai landasan secara umum maupun khusus, serta memberikan informasi pendukung di dalam pengerjaan penelitian ini. Dari teori dan data yang telah dikumpulkan, maka dilakukan pemodelan lambung kapal dengan berbagai variasi. Pada penelitian ini dilakukan pengklasifikasian model uji dalam 2 variasi utama, yaitu variasi aspek rasio pada sayap dan sudut cant pada winglet. Tahap terakhir yaitu dilakukan simulasi CFD. Simulasi yang dilakukan terbagi menjadi 2 macam, yaitu simulasi full viscous yang bertujuan untuk mendapatkan gaya angkat dan gaya hambat pada saat kapal dalam mode kecepatan terbang. Lalu simulasi free surface dilakukan untuk mengetahui gaya hambat dan gaya hambat akibat gaya hidrodinamis yang terjadi pada lambung kapal Wing in Surface Effect dalam mode planing hull. Tahap pengujian dengan aplikasi CFD dilakukan dengan tiga tahapan, yaitu tahap pre-processor, processor/solver, dan tahap post-processor [12].

\section{HASIL DAN PEMBAHASAN}

Pada analisa free surface dilakukan pengujian pada 2 model uji yaitu model $\mathrm{A}$ dengan aspek rasio rendah $\mathrm{AR}=1$ dan model $B$ dengan aspek rasio sedang $A R=3$. Kedua variasi model akan dilakukan analisis gaya hambat hidrodinamika di tiap tiap kecepatan pada masing masing sarat. Nilai sarat didapatkan berdasarkan nilai displacement pada sarat kondisi penuh dikurangi dengan displacement dari gaya angkat total hidrodinamika pada masing masing kecepatan.

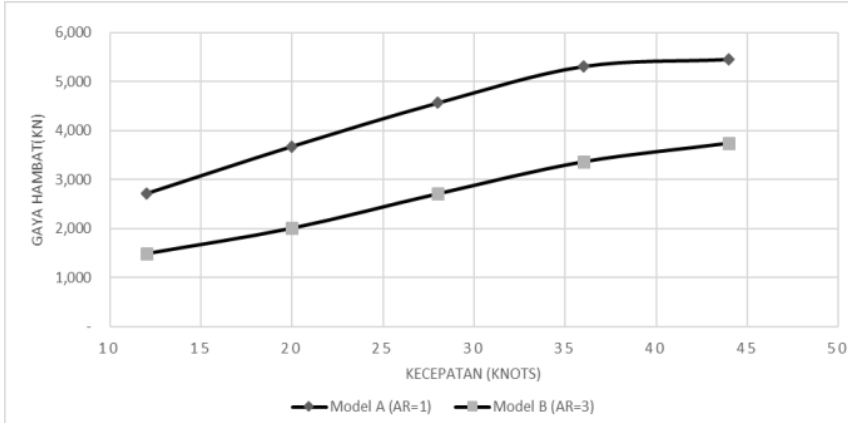

Gambar 9. Hasil Gaya Hambat Analisa Free Surface Variasi Aspek Rasio $\mathrm{AR}=1$ dan $\mathrm{AR}=3$.

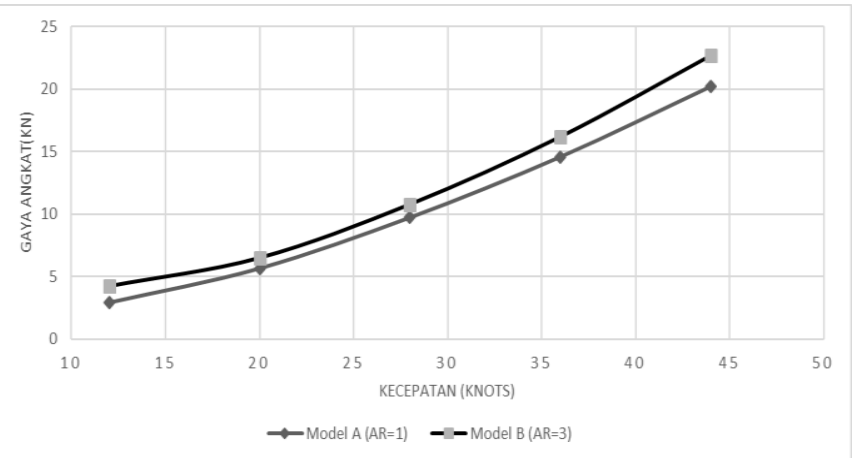

Gambar 10. Hasil Gaya Angkat Analisa Free Surface Variasi Aspek Rasio $\mathrm{AR}=1$ dan $\mathrm{AR}=3$. 


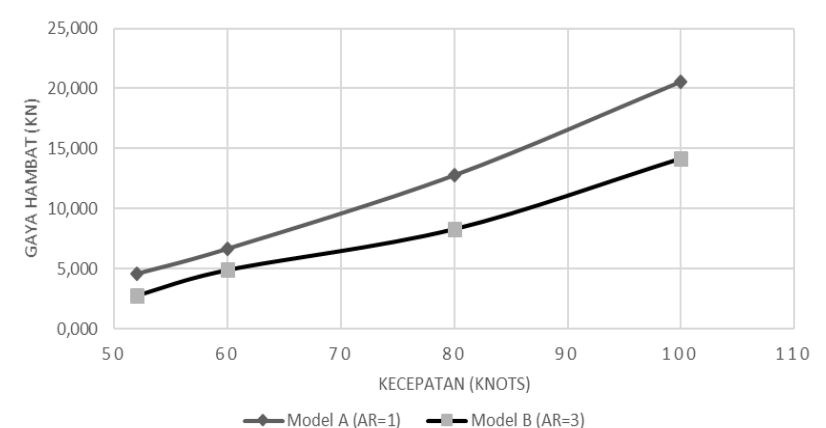

Gambar 11. Hasil Gaya Hambat Analisa Full Viscous Variasi Aspek Rasio $\mathrm{AR}=1$ dan $\mathrm{AR}=3$.

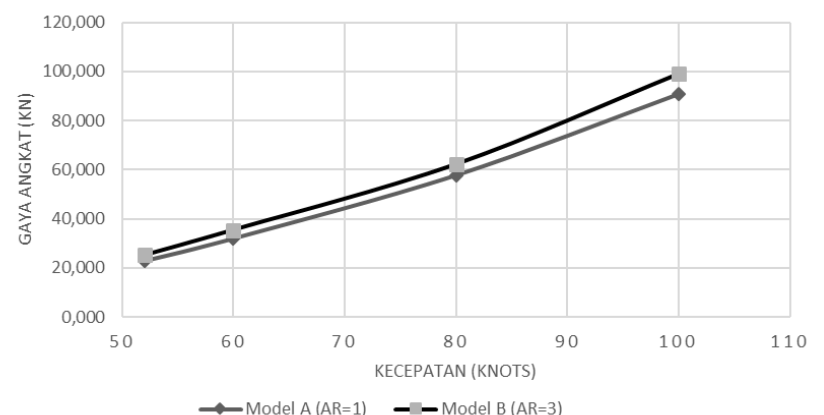

Gambar 12. Hasil Gaya Angkat Analisa Full Viscous Variasi Aspek Rasio $\mathrm{AR}=1$ dan $\mathrm{AR}=3$.

Dari Gambar 9 dan Gambar 10 dapat dilihat bahwa nilai gaya hambat total yang dihasilkan oleh model A dengan aspek rasio rendah $\mathrm{AR}=1$ lebih besar dari pada yang dihasilkan oleh model $B$ dengan aspek rasio sedang $A R=3$. Sedangkan, nilai gaya angkat yang dihasilkan oleh model A dengan aspek rasio rendah $\mathrm{AR}=1$ lebih kecil dari pada yang dihasilkan oleh model B dengan aspek rasio sedang $\mathrm{AR}=3$.

Pada pengujian full viscous dilakukan pengujian pada variasi 2 model dengan aspek rasio yang berbeda yaitu model A dengan aspek rasio rendah $\mathrm{AR}=1$ dan model $\mathrm{B}$ dengan aspek rasio sedang $A R=3$ serta tambahan 3 variasi model uji dengan variasi sudut cant berbeda pada winglet yaitu model $\mathrm{C}$ dengan sudut cant $30^{\circ}$, model $\mathrm{D}$ dengan sudut cant $45^{\circ}$ dan model $\mathrm{E}$ dengan sudut cant $60^{\circ}$. Semua model akan dianalisi gaya hambat aerodinamika dan gaya angkat aerodinamika pada masing masing kecepatan. Kecepatan pada pengujian full viscous merupakan kecepatan setelah kapal WISE memasuki kecepatan terbang di atas permukaan air.

Dari Gambar 11 dan Gambar 12 dapat dilihat bahwa nilai gaya hambat aero yang dihasilkan oleh model A dengan aspek rasio rendah $\mathrm{AR}=1$ lebih besar dari pada yang dihasilkan oleh model $B$ dengan aspek rasio sedang $A R=3$. Sedangkan, nilai gaya angkat aero yang dihasilkan oleh model A dengan aspek rasio rendah $\mathrm{AR}=1$ lebih kecil dari pada yang dihasilkan oleh model $\mathrm{B}$ dengan aspek rasio sedang $\mathrm{AR}=3$.

Dari Gambar 13 dan Gambar 14 dapat dilihat bahwa nilai gaya hambat aero yang dihasilkan oleh model $\mathrm{D}\left(\alpha=45^{\circ}\right)$ lebih kecil dari pada yang dihasilkan oleh model $\mathrm{C}\left(\alpha=30^{\circ}\right)$ dan model E $\left(\alpha=60^{\circ}\right)$. Sedangkan, nilai gaya angkat aero yang

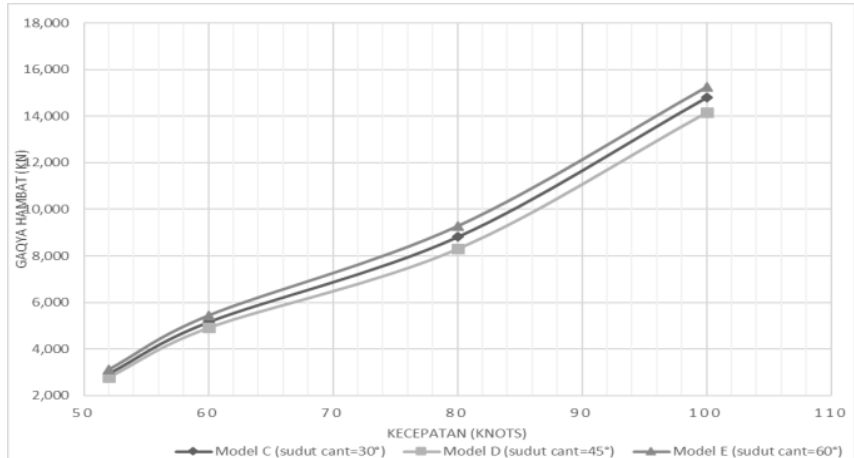

Gambar 13. Hasil Gaya Hambat Analisa Full Viscous Variasi Sudut Cant $\alpha=30^{\circ}, \alpha=45^{\circ}$ dan $\alpha=60^{\circ}$.

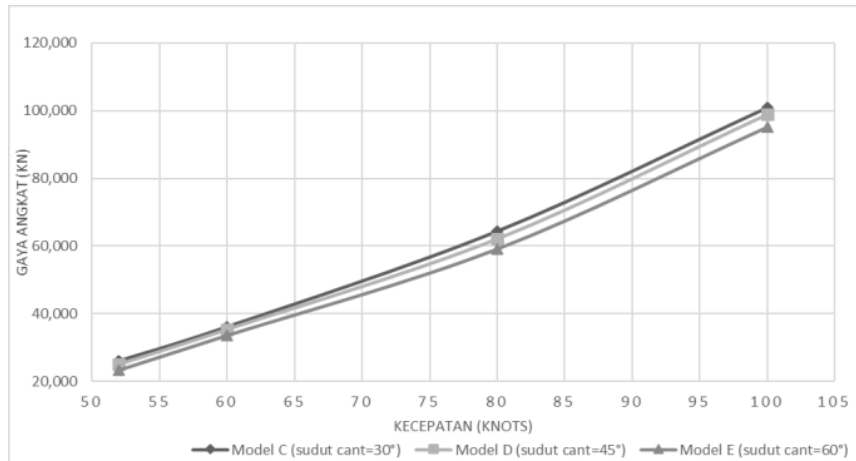

Gambar 14. Hasil Gaya Hambat Analisa Full Viscous Variasi Sudut Cant $\alpha=30^{\circ}, \alpha=45^{\circ}$ dan $\alpha=60^{\circ}$.

dihasilkan oleh model $\mathrm{C}\left(\alpha=30^{\circ}\right)$ lebih besar dari pada yang dihasilkan oleh model D $\left(\alpha=30^{\circ}\right)$ dan model E $\left(\alpha=30^{\circ}\right)$. Perbedaan nilai gaya hambat dan gaya angkat yang disebabkan tekanan yang berada di bawah sayap kapal WISE lebih besar dibandingkan tekanan di atas sayap kapal, pada titik temu diantara kedua perbedaan tekanan tersebut di ujung winglet sayap menghasilkan lilitan atau pusaran tekanan udara. Pusaran udara tersebut biasa disebut vortex, sehingga menghasilkan gaya hambat tambahan yang dirasakan oleh kapal WISE.

\section{KESIMPULAN}

Simulasi CFD dapat memberikan hasil data yang hampir sama dengan data yang didapatkan dengan uji eksperimental seperti nilai nilai gaya yang bekerja di sekitar objek yang dialiri fluida. Dari hasil pengujian CFD dapat disimpulkan bahwa:

1. Nilai hambatan model $B(A R=3)$ lebih kecil dibandingkan nilai hambatan yang dihasilkan model $\mathrm{A}(\mathrm{AR}=1)$. Nilai gaya angkat model $\mathrm{B}(\mathrm{AR}=3)$ lebih besar dibandingkan nilai gaya angkat yang dihasilkan model $\mathrm{A}(\mathrm{AR}=1)$. Hal ini dikarenakan induced drag yang dihasilkan model $\mathrm{A}(\mathrm{AR}=1)$ lebih besar dari model $\mathrm{B}(\mathrm{AR}=3)$. Jadi konfigurasi aspek rasio terbaik yang didapatkan dari penelitian ini adalah aspek rasio sedang $(\mathrm{AR}=3)$.

2. Nilai hambatan dengan sudut cant winglet $\alpha=45^{\circ}$ lebih kecil dibandingkan dengan sudut cant winglet $\alpha=30^{\circ}$ dan $\alpha=60^{\circ}$. Nilai gaya angkat dengan sudut cant winglet $\alpha=30^{\circ}$ lebih besar dibandingkan dengan sudut cant winglet $\alpha=45^{\circ}$ dan $\alpha=60^{\circ}$. Jadi semakin besar sudut cant maka nilai gaya angkat yang dihasilkan semakin kecil. Sedangkan konfigurasi sudut cant terbaik terhadap nilai hambatan adalah pada sudut $\alpha=45^{\circ}$. 


\section{DAFTAR PUSTAKA}

[1]

Anonymous, "Sinergi Pembangunan Ekonomi Maritim dan Pertahanan Keamanan Maritim," Indones. Marit. J., vol. 8, 2017.

[2] I. Putra, "Analisa Peluang Dan Ancaman Keamanan Maritim Indonesia," Sekolah Tinggi Teknologi Angkatan Laut Surabaya, 2017.

[3] M. Halloran and S. O'Meara, "Wing in Ground Effect Craft Review," Melbourne, 1999.

[4] J. Mostaccio, "Experimental Investigation Of The Aerodynamics Ground Effect Of A Tailless Lambda-Shaped UCAV With Wing Flaps," Ohio, 2006.

[5] A. E. Abbott, I. H., \& von Doenhoff, Theory of Wing Sections Including a Summary of Airfoil Data. New York: Dover Publications, Inc, 1949.
[6] A. Kundu, Aircraft Design. New York: Cambridge University Press, 2010.

[7] D. Raymer, "Aircraft Design: A Conceptual Approach,” Washington, 1992.

[8] D. Savitsky, "Hydrodynamic Design of Planing Hulls," 1964.

[9] Aron, "M80 Specification," Aron, 2010. [Online]. Available: http://www.aron.co.kr. [Accessed: 16-Jul-2018].

[10] Blueprint, "Lun-class ekranoplan Blueprint," drawingdatabase.com, 2018. [Online]. Available: https://drawingdatabase.com. [Accessed: 16-Jul-2018].

[11] J. Weierman, "Winglet Design And Optimization For UAVS," Oklahoma, 2010.

[12] I. K. A. P. Utama, "Investigaton of the Viscous Resistance Component of Catamaran Forms," University of Southampton, 1999. 